\title{
Efficiency Analysis of Islamic Microfinance Institutions: Case of East Java
}

\author{
Imron Mawardi*, Sri Ningsih, Wisudanto, Tika Widiastuti, Muhammad \\ Ubaidillah Al Mustofa
}

\author{
Faculty of Economics and Business, Universitas Airlangga, Indonesia \\ *Corresponding author email: ronmawardi@feb.unair.ac.id
}

\begin{abstract}
This study examines the efficiency of Islamic Micro Finance Institutions (IMFIs) in East Java using a two-stage study. The first stage is to test the efficiency of the IMFIs using the Data Envelopment Analysis (DEA) approach and the second stage is to look for factors that affect efficiency using the panel regression. The DEA is employed for 19 IMFIs with three years of financial observance. The study further tests the impact of some macroeconomic and internal factors on the efficiency of IFMIs. Findings show that KSPPS Sri Sejahtera succeeded to maintain the level of efficiency for three executive years. Besides, macroeconomic factors play no contribution in effecting the efficiency of IMFIs while some internal factors such as the size of IMFIs, Labor Cost and Financing to Deposit Ratio affect the efficiency significantly with different degrees of exposure.
\end{abstract}

Keywords: Efficiency, DEA, Tobit Regression, Islamic Micro Finance Intuitions

\section{INTRODUCTION}

According to the World Bank (2018), poverty is closely related to access to finance. Community with low financial access tend to have high poverty rates. The difficulty of accessing formal financial institutions makes it difficult for the poor to obtain business capital. The poor rural are not bankable, or in another sense, they do not have the collateral required by banking institutions. Consequently, the poor community forced to seek business capital from non-formal financial institutions with the consequences of high capital costs. With these facts, one solution is to empower the poor is by providing access to finance through Islamic Microfinance Institutions (IMFIs). IMFI programs are integrated with social aspects [1] which target low-income people to improve their welfare.

IMFIs have a sizeable potential market share. The Ministry of Cooperatives and Small and Medium Enterprises of the Republic of Indonesia (Kementerian Koperasi dan Usaha Mikro, Kecil, dan Menengah) reports that Micro, Small, and Medium Enterprises (MSMEs) have the most significant market share of the total business actors in Indonesia. Around 62.9 million business units are considered to be MSMEs or $99.99 \%$ of the market's business players. In comparison, only $0.01 \%$ or about 5400 enterprises are big businesses.

Alongside the massive number of units, MSMEs also absorb big numbers of the labor force. Micro Enterprises absorb the most significant number of the national workforce. It is estimated that around
107.2 million workers, or $89.2 \%$ of the total labor force, work in micro-enterprises. Small Enterprises absorb 5.7 million workers (equivalent to $4.74 \%$ from the national labor force), while Medium Enterprises only absorb 3.73 million laborers (3.11\%). Interestingly, Big Enterprises exclusively absorb around 3.58 million workers or about $3 \%$ of the total national workforce. Joining together, all MSMEs absorb approximately $97 \%$ of the national workforce. Consequently, policies to support these MSMEs must be carefully considered.

IMFIs, as one of the crucial pillars in the financial intermediation process, is needed by the community and MSMEs for consumption and production activities. These enterprises also needed a place to store the results of their businesses. Besides, in contrast to banking, IMFIs set simple conditions for the poor to obtain financing. However, the funding for these MSMEs has a high risk and possesses the potential to result in an unsustainable MSMEs. Therefore, to empower poor people, IMFIs must be adequately managed.

One measure of IMFIs performance is the efficiency of the management or management of the IMFIs. Efficiency is essential because as a business entity, IMFIs can maintain its sustainability so that it can continue to operate and empower poor people. The company is called efficient if several inputs used by management can produce maximum output. Therefore, the efficiency of IMFIs management can be seen from the input and output side. Efficient management can produce greater output with the 
same input or the same production with smaller raw materials. Measuring the efficiency of IMFIs in Indonesia and examining the determinant factors of efficiency is essential. Strategies to increase efficiency, both from the input and output side, can be formulated after conducting the efficiency analysis of IMFIs.

There are several efficiency studies in IMFIs. However, these studies examine the financial efficiency of MFIs as measured by financial ratios such as BOPO (operating costs / operating income), net margin, Financing Deposit Ratio (FDR), and Return on Assets (ROA). This study examines the efficiency of IMFIs management using a two-stage study analysis. The first stage is to test the efficiency of the IMFIs using the Data Envelopment Analysis (DEA) approach. This method provides scores of efficiency for IMFIs in particular year. After examining the score of efficiency, the second stage is to look for factors that influence efficiency by employing the panel regression using several variables represent internal and external factors. The internal factors include assets, capital, employee costs, Non-Performing Financing (NPF), and Financing Deposit Ratio (FDR), while the external or macroeconomic factors include economic growth, and inflation.

\section{LITERATURE REVIEW}

\subsection{Efficiency of IMFIs}

According to Ghiselli and Brown [2] efficiency is the proportion of particular outputs and inputs. [3] adds that efficiency is a ratio of effectiveness that minimizes wasted time, effort, and skills. According to [4], "Efficient is doing the things right," which means doing everything in the right way to get optimal results. [5] explain efficiency as the ability to complete work correctly. In a mathematical view, it is defined as calculating the ratio of output and input or the number of results produced from a particular input used.

Three factors cause efficiency, [6] state: (1) If the same input can produce a more massive output, (2) With a smaller input it can produce the same outcome, (3) With a more considerable input can produce a larger percentage of output. However, [7] explains that the company operates at an inefficient level due to two things, namely (1) failure to use resources efficiently or inefficiency in use, and (2) inability of firms to combine these resources optimally. A maximum profit is achieved by producing the highest output with a determined amount of input (technical efficiency) and create a product or performance with the right combination of resources at a certain price level (allocative efficiency) [8]. Achieving efficient management is an essential part of a financial institution, in this case, IMFIs. As a business-based or profit-oriented institution, IMFI continuously improves its business performance.

One way to measure performance is through an assessment of the level of efficiency. In other words, efficiency provides an overview of the business performance of financial institutions [9] As an illustration, for customers, an efficient IMFIs provides an advantage because the transaction costs at the IMFIs are cheaper than other (inefficient) financial institutions. For the government, an efficient IMFIs will offer benefits in the form of corporate taxes. Therefore, stakeholders, especially the government, and monetary authorities, and always pay attention to the efficiency issue of the IMFIs.

Assessment of the level of efficiency in the financial industry is urgent, along with the high level of competition in the industry. This happened because of the rapid growth in the number of Islamic financial institutions. Therefore, the assessment of efficiency can be an essential indicator in seeing the ability of IMFIs to survive in the face of intense competition in the financial industry in Indonesia [10]. According to [11] technically, there are three concepts in the efficiency of financial institutions, in this case, banking, namely: (1) cost efficiency; (2) standard profit efficiency; (3) alternative profit efficiency. These three concepts are based on the belief in economic activity in seeing prices and market competition. They are considered the foundation for analyzing the level of economic efficiency for financial intermediaries.

One of the noble teachings of Islam is prohibiting the deeds of israf and tabdzir as described in the word of Allah SWT in Surah Al-An'am verse 141 and Surah Al Isra 'verse 27. The implementation of these verses can be a reference in applying the concept of efficiency and avoid the misuse of economic resources.

\subsection{Impact of Non-Performing Financing on IMFI Efficiency}

Non-performing financing (NPF) or non-performing loans (NPL in conventional banks) is an indicator of the health of the asset quality of financial institutions which shows the ratio for lousy funding [12]. This ratio indicates that the amount of problem financing which reflects the risk of the financing over the 
control of an Islamic microfinance institution. This low quality of funding will have an impact on the efficiency of IMFIs [13]. This non-performing loan affects the level of efficiency because basically, the IMFI will incur additional costs related to operational activities that are not value-added (handling and supervising the non-performing loan collection process). Besides, the non-performing loans will also disrupt the MFI's operations, especially the liquidity side, which results in inefficiency in utilizing all available resources.

Several studies examine the relationship between NPF and Efficiency, namely in banking [14], [15] [16], [17] and found a negative relationship between NPF and Efficiency. As the IMFIs act as intermediary financial institutions such as banks, we hypothesize that NPF negatively affects the IMFI's efficiency.

\subsection{Financial to Deposit Ratio and IMFI Efficiency}

Financing to Deposit Ratio (FDR) reflects the amount of funding allocation from funds collected from the public. [18] explain that the Financing to Deposit Ratio is an indicator to measure the level of performance, in terms of carrying out its functions, as an intermediary institution that collects funds from the community and allocated these funds. FDR can be determined by a comparison between the amount of funds channeled with public funds collected, such as time deposits, current accounts, and savings [19]

Previous research on banking by [20] explains that the greater the disbursed financing, the more efficient Islamic banks operate, and proves that FDR is positively affect the efficiency of Islamic banks. This can be used as a basis because IMFIs, especially BMTs or Sharia cooperatives, operates in collecting fundings and distributing financings. Thus, we hypothesize a positive relationship between FDR and efficiency of IMFIs

\subsection{Capital and IMFI Efficiency}

Increasing the quality and quantity of a bank's capital can increase the ability of risk mitigation. The capital serves as a buffer when a financial, economic crisis occurs, which harms financial system stability. Having large capital helps avoid financial distress [17] and allow IMFIs to be more efficient since less leverage is used [21]. Large capital will provide financial stability, increase the financial performance of the IMFI and its efficiency.

\subsection{The Size of IMFI and its efficiency}

The greater the number of assets owned by an IMFI helps increase efficiency [22] [23] IMFIs that operates with more considerable assets, could benefits from economies of scale [24]. The assets can use to finance investment on adopting new technologies that will reduce management costs [21] or invest on several other advantages that have an impact on increasing the level of efficiency [25] Previous research by [21]; [25]; [3]; [26] revealed the positive effect of assets and the level of banks' efficiencies. Researches on MFI also show a similar positive significant impact on efficiency [24]; [13]; [27].

\subsection{Economic Growth and IMFI efficiency}

Economic growth is a factor from a macroeconomic perspective that can affect the efficiency of a financial intermediary. In general, when economic growth achieved, the economic capacity will also increase so that the production sector (aggregate supply) and the demand side (aggregate demand) increase simultaneously. Economic growth will lead to an excellent economic condition and financial stability. Higher economic growth led to an increase in people's income so that the default ratio will be relatively low. Loan stability will have an impact on the level of efficiency of the MFI [24]. Consequently, profitable economic growth will make many people save their funds and will strengthen cash flow or funding from MFIs [17].

Several previous studies revealed the relationship of economic growth to efficiency [26] and found that there was no relationship between economic growth and efficiency in Islamic banks. The findings [28] reveal that economic growth negatively affects the banking efficiency in Turkey. While other impressive results [15], [17] found that there is a positive relationship in banking, similarly [24] found a positive effect of economic growth on the level of efficiency in MFI. The existence of these differences is an impressive thing to examine. The hypothesis taken by the researchers is to have a positive relationship.

\subsection{Inflation and IMFI efficiency}

Inflation is a condition in which there is a general price increase of a good and service over a certain period [18]. The condition of an increase in the price of one or two kinds of goods is not said to be inflation. Inflation happens if the rise in the price of goods and services can affect the price of most other goods and services. A rapid increase in prices 
decreases people's purchasing power and indirectly reduce the level of saving and investment due to increased public consumption.

[17] reveal that inflation has a positive impact on efficiency due to Islamic banks' anticipation of inflation so that they can adjust their operations that will affect sharpening its efficiency. [24] found positive a positive nexus of inflation on efficiency. MFIs favor inflation since it reduces the real value of non-performing loans. Besides, in conventional MFIs, higher inflation will provide higher income as people expect higher interest rates in the future.

\section{METHOD}

\subsection{Research Approach and Data}

This study is a quantitative approach employing two stages of analysis. The first stage is to get the score of efficiency of each unit by utilising the Data Envelopment Analysis (DEA) method and the second stage of Panel regression. This study uses secondary data, obtained through IMFIs' financial reports, journals, books and the IMFIs's governance modules. The review uses the sample data from 19 IFMIs out of 25 IFMIs with legal status in East Java, covering the period of 2017-2019. The sampling technique used is purposive sampling technique with the following criteria:

1. IMFI which has a license or permit to operate in East Java Province

2. IMFI with assets of more than IDR 10 billion

3. IMFI that publish financial report in the last three years

\subsection{Data Envelopment Analysis (DEA)}

DEA is a non-parametric method that applies a linear programming model to calculate the ratio of output to input ratios for all units being compared. This method was first developed by [29] through their paper published by the European Journal of Operation Research in 1978. This technique has since become very popular as a management tool and is widely used to measure efficiency assessments. Leibenstein and Maital believe that DEA is a superior technique in measuring the efficiency of the financial industry and is commonly applied in assessing institutions' performance in the form of companies, schools, and others. IMFIs performance efficiency is seen by calculating the ratio between its output and input through the equation.

Data Envelopment Analysis (DEA) is a nonparametric approach method, a linear programmingbased technique to calculate the input and output of all compared DMUs (Decision Making Units). The
DEA model does not differentiate between efficient firm performance because all efficient units have an efficiency score equal to 1. DEA analysis was performed using MAXDEA software. The input variables used include assets, third party funds, employee costs, and operational costs. At the same time, the output variable holds Profit or Remaining Operating Income and Financing. The data used is secondary data in panel data, which is a combination of cross-section data and time-series data.

$$
\begin{aligned}
& \boldsymbol{e}_{s}=\frac{\sum_{i=1}^{m} \boldsymbol{u}_{i} \boldsymbol{Y}_{i s}}{\sum_{j=1}^{n} \boldsymbol{\nu}_{j} \boldsymbol{\mathcal { X }}_{j s}} \\
& \text { Where: } \\
& e_{s}=\text { The Efficiency of IMFI } s \\
& m=\text { output IMFI } s \text { observed } \\
& n=\text { input IMFI } s \text { observed } \\
& y_{i s}=\text { output } i \text { produced by IMFI s } \\
& x_{j s}=\text { output } j \text { produced by IMFI s } \\
& u_{i}=\text { output weight } \\
& v_{j}=\text { input weight }
\end{aligned}
$$

The ratio of efficiency (es) in the above equation is then maximized to select the optimum weight by:

$$
\frac{\sum_{i=1}^{m} u_{i} y_{i r}}{\sum_{j=1}^{n} v_{j} x_{j r}}
$$

The above equation will produce a ratio, where ' $n$ ' represents the number of IMFIs in the sample, and ' $r$ ' is the type of IMFI in the study. The ratio number will vary from zero to one. IMFI is said to be efficient if it has a ratio number close to one or 100 percent. On the other hand, if it is close to zero, it indicates lower efficiency. At DEA, each IMFIs can determine its weight and ensure that the value chosen will produce the best performance measure.

\subsection{Panel Regression}

This quantitative research applies Panel Regression using the Random Effect, this selection is based on the result of Lagrange Multiplier Tests for Random Effects. The method is selected to examine the influence of determining factors on efficiency of IMFIs. The sample is 19 IMFIs situated in East Java Province with three years of financial observance 
from 2017 - 2019. The independent variables in the model in this study include Total Asset, Capital, Employee Costs (EC), Non-performing Financing (NPF), Financing Deposit Ratio (FDR), Inflation (CPI), and Economic Growth (Regional Gross Domestic Product/GRDP). The efficiency score from the DEA is then regressed with the independent variable, which is assumed to affect the efficiency level of the IMFIs. The panel regression is written as follows:

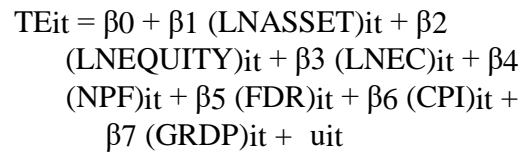

\section{RESULTS AND DISCUSSION 4.1 Calculation of Efficiency Score}

Based on annual data on IMFIs in East Java, Indonesia, for the period 2017 to 2019, an efficiency value (score) is obtained, which has a scale of 0 to 1 . If one of the IMFIs has a score of 1 , it can be said that the IMFI is efficient. However, if it is less than one, then the MFI is less efficient and a score of zero indicates an inefficient IMFIs.
Looking at the results of the efficiency level scores in Table 1, several IMFIs deserve attention. DMU 16, namely KSPPS Sri Sejahtera Jawa Timur, has been consistently able to provide efficient performance in the last three years. This is evidenced by the DEA efficiency score of 1 for three consecutive years. In other words, the DMU 16 succeeds in maximizing the output with the available inputs. In contrast, DMU 18 has the smallest possible level of efficiency over the last three years, which is 0.04 in 2017. Besides, some DMUs have efficiency performance that tends to increase every year. Some IMFIs such as DMU 2, 3, 6, 17, 18, and 19 experienced improved performance and resulted in increased levels of efficiency. This is the success of management in evaluating and making improvements to IMFI governance. On the other hand, some IMFIs such as DMU 5, 9, 14, and 15 experienced a decrease in the observed efficiency levels from 2017 to 2019. Some IMFIs such as DMU $7,10,13,15$ and 16 have a stable performance from year to year. However, some DMUs such as 7, 10 and 13 should improve their performance so that they can get closer to a more efficient level. From these results, three categories of IMFIs can be made, which have increased, decreased and stable performance efficiency.

TABLE 1. Efficiency score

\begin{tabular}{|l|l|l|l|l|}
\hline \multicolumn{1}{|c|}{ IMFIs } & DMU & 2017 & 2018 & 2019 \\
\hline KSPPS BMT Bina Ummat Sejahtera Jawa Timur & DMU 1 & 0.80 & 0.89 & 0.89 \\
\hline Koperasi BMT Mandiri Sejahtera Jatim & DMU 2 & 0.10 & 0.73 & 0.81 \\
\hline KSP Syariah BMT Maslahah Jatim & DMU 3 & 0.50 & 0.62 & 0.66 \\
\hline KSPPS BMT NU Gapura Jatim & DMU 4 & 0.96 & 0.80 & 0.83 \\
\hline Koperasi Syariah NURI Jatim & DMU 5 & 1.00 & 0.84 & 0.82 \\
\hline KSPPS Syirkah Fastabiqul Khoirot Jawa Timur & DMU 6 & 0.61 & 0.70 & 0.78 \\
\hline Koperasi Agro Niaga Indonesia (Kanindo) Syariah Jawa Timur & DMU 7 & 0.79 & 0.79 & 0.79 \\
\hline KSPPS BMT Nurul Ummah Ngasem Jawa Timur & DMU 8 & 0.68 & 0.94 & 0.70 \\
\hline $\begin{array}{l}\text { Koperasi Konsumen Al Iqtishad Lil Muamalah } \\
\text { Mawaddah Syariah (KOIM) Jawa Timur }\end{array}$ & DMU 9 & 1.00 & 0.71 & 0.71 \\
\hline KSPPS BMT Bina Insan Mandiri Jawa Timur & & & & \\
\hline KSPPS BTM Surya Melati Abadi Jawa Timur & DMU 10 & 0.73 & 0.75 & 0.75 \\
\hline KSPPS BMT Permata Jatim & DMU 11 & 0.67 & 0.69 & 0.69 \\
\hline KSPPS BMT As Salam Jawa Timur & DMU 12 & 0.21 & 0.87 & 0.87 \\
\hline KSPPS Darumafatihil Ulum Jawa Timur & DMU 13 & 0.84 & 0.84 & 0.84 \\
\hline Koperasi Produsen Agro Niaga Jabung Syariah Jawa Timur & DMU 14 & 0.95 & 0.82 & 0.84 \\
\hline KSPPS Sri Sejahtera Jawa Timur & DMU 15 & 0.99 & 0.95 & 0.95 \\
\hline KSPPS Mitra Usaha Ideal (MUI) Jatim & DMU 16 & 1.00 & 1.00 & 1.00 \\
\hline KSPPS BMT Amanah Ummah Jawa Timur & DMU 17 & 0.54 & 0.79 & 0.83 \\
\hline KSPP Syariah Madani Jawa Timur & DMU 18 & 0.04 & 0.44 & 0.44 \\
\hline
\end{tabular}


efficiency. The efficiency score obtained in the first stage will be used as the dependent variable in panel regression. The results of Panel regression are presented in in the table 2.

TABLE 2. Panel regression result

\begin{tabular}{|c|r|r|r|r|}
\hline Variable & Coefficiet & Std. Error & t-Statistic & Prob. \\
\hline LN_ASSET & 0.193601 & 0.029083 & 6.656910 & 0.0000 \\
\hline LN_EQUITY & 0.019350 & 0.020777 & 0.931304 & 0.3570 \\
\hline LN_LABOR COST & -0.239133 & 0.018846 & -12.68898 & 0.0000 \\
\hline NPF & -0.304432 & 0.350470 & -0.868640 & 0.3900 \\
\hline FDR & 0.713027 & 0.048249 & 14.77822 & 0.0000 \\
\hline CPI & 0.077021 & 0.076933 & 1.001144 & 0.3225 \\
\hline GDRP & 2.855376 & 2.463442 & 1.159100 & 0.2530 \\
\hline C & -15.81947 & 13.79660 & -1.146621 & 0.2580 \\
\hline
\end{tabular}

Source: Author calculation using EViews, 2020

Based on the empirical result, there are several findings worth considering. The size variable positively affects the IMFI efficiency. This effect is in accordance with the results of several studies by [27], [24], [13]. Having higher assets will lead to more efficient IMFIs as a daily operation can benefit from its economies of scale. IMFIs with higher assets can reduce the operating costs more than IMFIs with smaller assets.

Capital does not affect the efficiency of an IMFIs. This indicates that a large amount of capital will not affect the efficiency level of the IMFI itself. On the other hand, high employee expenses bring harms to the efficiency of the IMFIs. Less burden on employees' expenses tends to increase efficiency [13]. This shows that IMFIs that spend more to finance these expenses which will have an impact on their financial performance [24] and will lead to less efficiency in utilizing existing inputs to achieve potential outputs [28] IMFIs need to evaluate the expenses incurred for employee salaries to reach an optimum point so that efficiency will be achieved.

FDR positively affect the dependent variable of efficiency; this is in accordance with the research of [20]. The larger the portion of funds allocated for financing will make IMFIs more efficient in managing resources. An increase in the FDR ratio indicates an increase in lending or funding. The primary source of income for MFIs comes from the profits from financing so that when the funding channelled by IMFIs increases, the chances of getting a higher profit are also more significant and this will increase its operational efficiency.

East Java's GRDP growth has a positive but insignificant effect, or in other words, economic growth in East Java Province does not have a real contribution in achieving the efficiency of IMFIs. This finding goes in line with [26], which found that there is no effect of economic growth on efficiency. The uncertainty of the macroeconomic environment and volatile economic growth which can result in financial institutions suffering from lower demand of financial services, increasing loan defaults, and thus reducing output.

Another macroeconomic variable of inflation does not significantly affect the efficiency of IMFIs. In other words, an increase in the rate of inflation does not contribute to achieving the level efficiency of IMFIs. [30] in [31] argue that economic conditions and financial markets influence individual financial institutions with a level of cost efficiency and their financial operations. Inflation, which weakens the income of the community or increases the risk of default, has no impact on the efficiency of the MFI itself.

\section{CONCLUSION}

This study measures and analyses the level of efficiency and to find determinants of efficiency in IMFIs in East Java, Indonesia, for the period 20172019. In the first stage, DEA measurement found that a few IMFIs that have reached efficiency, but most MFIs are experiencing an upward trend. Only one IMFI can maintain the efficient level for three executive years, namely KSPPS Sri Sejahtera Jawa Timur. Then at the second stage, the panel regression is applied, and it was found that Asset and FDR had a significant positive effect on IMFIs' efficiencies. In contrast, employee expenses harmed IMFI efficiency. Interestingly, macroeconomic variables, namely GRDP and inflation, do not have a significant impact on IMFIs as well as NPF and business capital.

Based on these results, IMFIs in East Java Province still need to conduct further evaluations, especially on variables that have a significant effect on determining the level of efficiency. Most IMFIs have not reach the level efficiency. The government, as well as stakeholders, need to find solutions to these problems, considering the growth and market share of IMFIs that is still relatively small, and many have not yet achieved the level of efficiency. IMFI 
is a key player, especially in financing low-income groups. Therefore, the management of IMFIs needs to be developed better and achieve the efficiency. As A Result, investors or the public will be more interested in saving or investing in IMFIs. The customers who are being financed will also receive the benefit by the development of IMFIs.

\section{REFERENCES}

[1] Iqbal $\mathrm{Z}$ and Mirakhor A. Economic development and Islamic finance (Washington: The World Bank). 2013

[2] Syamsi Ibn. Efisiensi, Sistem, dan Prosedur Kerja (Jakarta: PT Bumi Aksara). 2004

[3] Ascarya A and Yumanita D. Mencari solusi rendahnya pembiayaan bagi hasil di perbankan syariah Indonesia Buletin Ekonomi Moneter dan Perbankan 8(1) pp 7-43. 2005

[4] Karim Mohd Zaini Abd, Chan Sok-Gee Chan, and Sallahudin Hassan. Bank Efficiency and Non-Performing Loan: Evidence From Malaysia and Singapore Prague Economic Paper 2 pp 118- 32. 2010

[5] Muharam $\mathrm{H}$ and Pusvitasari. Analisis perbandingan efisiensi bank syariah di Indonesia dengan metode data envelopment analysis (Periode tahun 2005) Jurnal Ekonomi dan Bisnis Islam 2(3) pp 80-166. 2007

[6] Hansen, D. R. dan Maryanne M. Mowen. Managerial Accounting, 8. 2003

[7] Leibenstein H. Allocative versus X" Efficiency" American Economic Review 56 pp 392-415. 1966

[8] Ascarya, A., \& Yumanita, D. Mencari solusi rendahnya pembiayaan bagi hasil di perbankan syariah Indonesia. Buletin Ekonomi Moneter dan Perbankan, 8(1), 7-43. 2005

[9] Hidayat R 2014 Efisiensi perbankan syariah: teori dan praktik (Bekasi: Gramata Publishing). 2014.

[10] Firdaus Muhammad Faza and Muhamad Nadratuzzaman Hosen. Efisiensi Bank Umum Syariah Menggunakan Pendekatan Two-Stage Data Envelopment Analysis Buletin Ekonomi Moneter dan Perbankan Bank Indonesia 16(2) pp 167-88. 2013

[11] Berger A N and Mester L J. Efficiency and productivity change in the US commercial banking industry: A comparison of the 1980s and 1990s pp 97-5. 1997

[12] Garza-García J G. Determinants of bank efficiency in Mexico: a two-stage analysis Applied Economics Letters 19(17) 167982. 2012

[13] Khan A and Shireen S. Drivers of financial and operational efficiency of MFIs: empirical evidences from Eastern Europe and Central Asia Benchmarking: An International Journal. 2020

[14] Batir T E, Volkman A, and Gungor B. Determinants of bank efficiency in Turkey: Participation banks versus conventional banks Borsa Istanbul Review 17(2) pp 86-96. 2017

[15] Garza-García J G. Determinants of bank efficiency in Mexico: a two-stage analysis Applied Economics Letters 19(17) 167982. 2012

[16] Abd Karim M Z, Chan S G, \& Hassan, S. Bank efficiency and non-performing loans: Evidence from Malaysia and Singapore Prague Economic Papers 2(1). 2010.

[17] Sufian F and Kamarudin F. Determinants of revenue efficiency of Islamic banks International Journal of Islamic and Middle Eastern Finance and Management. 2015.

[18] Arfiani L R and Mulazid A S. Analisis Faktor-Faktor yang Mempengaruhi Tingkat Bagi Hasil Simpanan Mudharabah pada Bank Umum Syariah Indonesia Studi Kasus pada Bank Umum Syariah di Indonesia Periode 2011-2015 IQTISHADIA: Jurnal Ekonomi \& Perbankan Syariah 4(1) pp 1-23. 2017.

[19] Choirudin A and Praptoyo S. Analisis Faktor yang Mempengaruhi Pembiayaan Bagi Hasil Mudharabah pada Bank Umum Syariah Jurnal Ilmu dan Riset Akuntansi 6(9) pp 1-22. 2017.

[20] Sufian F, and Noor M A N M. The determinants of Islamic banks' efficiency changes International Journal of Islamic and Middle Eastern Finance and Management. 2009

[21] Said J, Hasnan S, Ismail F, Majid M S A, and Rahim R A. Efficiency of Islamic and conventional banks in Malaysia Journal of Financial Reporting and Accounting. 2013

[22] Kumar N and Sensarma R. Efficiency of 
microfinance institutions in India: A stochastic distance function approach Journal of Emerging Market Finance 16(2) pp 151-68. 2017

[23] Wijesiri M, Yaron J, and Meoli M. Assessing the financial and outreach efficiency of microfinance institutions: Do age and size matter Journal of Multinational Financial Management 40 63-76. 2017.

[24] Hussain H I, Kot S, Kamarudin F, and Wong C M. The Nexus of Competition Freedom and the Efficiency of Microfinance Institutions Journal of Competitiveness 12(2) 67. 2020

[25] Othman N, Abdul-Majid M, and AbdulRahman A. Partnership financing and bank efficiency Pacific-Basin Finance Journal 46 pp 1-13. 2017

[26] Mezzi N. Efficiency of Islamic banks and role of governance: empirical evidence Managerial Finance. 2018

[27] Bensalem S, and Ellouze A. Profitorientation and efficiency in microfinance industry: an application of stochastic frontier approach INFOR: Information Systems and Operational Research 57(3) pp 411-29. 2019

[28] Batir T E, Volkman A, and Gungor B. Determinants of bank efficiency in Turkey: Participation banks versus conventional banks Borsa Istanbul Review 17(2) pp 86-96. 2017.

[29] Charnes A, Cooper W W, and Rhodes E. Measuring the efficiency of decision making units European journal of operational research 2(6) pp 429-44. 1978

[30] Yi-Kai Chen, Joseph R Mason dan Eric J Higgins. Does Bank efficiency Change With The Business Cycle? The Relationship Between Monetary Policy, Economic Growth, and Bank Condition (Mimeo: Emporia State University). 2001.

[31] Bisri B. Pengukuran Tingkat Efisiensi Bank Umum. 2016.

[32] Abd Karim M Z, Chan S G, \& Hassan, S 2010 Bank efficiency and non-performing loans: Evidence from Malaysia and Singapore Prague Economic Papers 2(1)

[33] Arfiani L R and Mulazid A S 2017 Analisis Faktor-Faktor yang Mempengaruhi Tingkat Bagi Hasil Simpanan Mudharabah pada Bank Umum Syariah Indonesia Studi Kasus pada Bank Umum
Syariah di Indonesia Periode 2011-2015 IQTISHADIA: Jurnal Ekonomi \& Perbankan Syariah 4(1) pp 1-23

[34] Ascarya A and Yumanita D 2005 Mencari solusi rendahnya pembiayaan bagi hasil di perbankan syariah Indonesia Buletin Ekonomi Moneter dan Perbankan 8(1) pp 7-43

[35] Batir T E, Volkman A, and Gungor B 2017 Determinants of bank efficiency in Turkey: Participation banks versus conventional banks Borsa Istanbul Review 17(2) pp 86-96

[36] Bensalem S, and Ellouze A 2019 Profitorientation and efficiency in microfinance industry: an application of stochastic frontier approach INFOR: Information Systems and Operational Research 57(3) pp 411-29

[37] Bisri B 2016 Pengukuran Tingkat Efisiensi Bank Umum Syariah Di Indonesia dan Determinannya Moneter-Jurnal Akuntansi dan Keuangan 3(2)

[38] Charnes A, Cooper W W, and Rhodes E 1978 Measuring the efficiency of decision making units European journal of operational research 2(6) pp 429-44

[39] Yi-Kai Chen, Joseph R Mason dan Eric J Higgins 2001 Does Bank efficiency Change With The Business Cycle? The Relationship Between Monetary Policy, Economic Growth, and Bank Condition (Mimeo: Emporia State University)

[40] Choirudin A and Praptoyo S 2017 Analisis Faktor yang Mempengaruhi Pembiayaan Bagi Hasil Mudharabah pada Bank Umum Syariah Jurnal Ilmu dan Riset Akuntansi 6(9) pp 1-22

[41] Berger A N and Mester L J 1997 Efficiency and productivity change in the US commercial banking industry: A comparison of the 1980s and 1990s pp 97-5

[42] Darrat Ali F, Topuz Can, and Yousef Tarik 2002 Assessing cost and technical efficiency of banks in Kuwait paper presented at the ERF's 8th Annual Conference (Cairo) pp 1-22

[43] Firdaus Muhammad Faza and Muhamad Nadratuzzaman Hosen 2013 Efisiensi Bank Umum Syariah Menggunakan Pendekatan Two-Stage Data Envelopment Analysis Buletin Ekonomi Moneter dan Perbankan Bank Indonesia 
16(2) pp 167-88

[44] Karim Mohd Zaini Abd, Chan Sok-Gee Chan, and Sallahudin Hassan 2010 Bank Efficiency and Non-Performing Loan: Evidence From Malaysia and Singapore Prague Economic Paper 2 pp 118- 32

[45] Garza-García J G 2012 Determinants of bank efficiency in Mexico: a two-stage analysis Applied Economics Letters 19(17) 167982

[46] Hidayat R 2014 Efisiensi perbankan syariah: teori dan praktik (Bekasi: Gramata Publishing)

[47] Hussain H I, Kot S, Kamarudin F, and Wong C M 2020 The Nexus of Competition Freedom and the Efficiency of Microfinance Institutions Journal of Competitiveness 12(2) 67

[48] Iqbal Z and Mirakhor A 2013 Economic development and Islamic finance (Washington: The World Bank)

[49] Karim Adiwarman A 2011 Ekonomi Miko Islam (Jakarta: Rajawali Press)

[50] Khan A and Shireen S 2020 Drivers of financial and operational efficiency of MFIs: empirical evidences from Eastern Europe and Central Asia Benchmarking: An International Journal

[51] Kumar N and Sensarma R 2017 Efficiency of microfinance institutions in India: A stochastic distance function approach Journal of Emerging Market Finance 16(2) pp 151-68

[52] Leibenstein H 1966 Allocative versus X" Efficiency" American Economic Review 56 pp 392-415

[53] Liebenstein H and S Maital 1992 Empirical Estimation and Partitioning of $\mathrm{X}$ Inefficiency: A Data-Envelopment Approach American Economic Review 2 pp 428-33

[54] Maryanne D R H and Mowen M 2003 Cost Management, Accounting and Control

[55] Mezzi N 2018 Efficiency of Islamic banks and role of governance: empirical evidence Managerial Finance

[56] Muharam H and Pusvitasari 2007 Analisis perbandingan efisiensi bank syariah di Indonesia dengan metode data envelopment analysis (Periode tahun 2005) Jurnal Ekonomi dan Bisnis Islam 2(3) pp 80-166

[57] Othman N, Abdul-Majid M, and AbdulRahman A 2017 Partnership financing and bank efficiency Pacific-Basin Finance Journal 46 pp 1-13

[58] Said J, Hasnan S, Ismail F, Majid M S A, and Rahim R A 2013 Efficiency of Islamic and conventional banks in Malaysia Journal of Financial Reporting and Accounting

[59] Syamsi Ibnu 2004 Efisiensi, Sistem, dan Prosedur Kerja (Jakarta: PT Bumi Aksara)

[60] Sufian Fadzlan, Fakarudin Kamarudin and Annuar md Nassir 2016 Determinants of Efficiency in the Malaysian Banking Sector: Does Bank Origins Matter Intellectual Economics 10(1) 38-54

[61] Sufian F and Kamarudin F 2015 Determinants of revenue efficiency of Islamic banks International Journal of Islamic and Middle Eastern Finance and Management

[62] Sufian F, and Noor M A N M 2009 The determinants of Islamic banks' efficiency changes International Journal of Islamic and Middle Eastern Finance and Management

[63] Wijesiri M, Yaron J, and Meoli M 2017 Assessing the financial and outreach efficiency of microfinance institutions: Do age and size matter Journal of Multinational Financial Management 40 63-76

[64] Worldbank 2018. Retrieved from https://www.worldbank.org/en/topic/fina ncialinclusion/overview\#1 